${ }^{6}$ Robinson, H M, jun, and Stone, J H, Archives of Dermatology, 1970, 101, 462.

7 Dawson, K P, Archives of Disease in Childhood, 1973, 48, 239.

${ }^{8}$ Parker, W A, and Gumnit, R J, Neurology, 1974, 24, 1178.

${ }^{2}$ Wilson, J T, Höjer, B, and Rane, A, Clinical Pharmacology and Therapeutics, 1976, 20, 48.

10 Juhlin, L, Michaëlsson, G, and Zetterström, O, fournal of Allergy and Clinical Immunology, 1972, 50, 92.

11 Berlin, A, et al, Scandinavian fournal of Clinical and Laboratory Investigation, 1972, 29, 281.

12 Mac Gee, J, Annals of Chemistry, 1970, 42, 421.

13 Ehrnebo, M, et al, European fournal of Clinical Pharmacology, 1971, 3, 189.

14 Norell, E, Liljenberg, G, and Gamstorp, I, European fournal of Neurology, $1975,13,232$.

${ }^{15}$ Chien, L T, Ceballos, R, and Benton, J W, jun, Alabama fournal of Medical Sciences, 1970, 7, 318.
${ }^{16}$ Greenberg, L M, et al, Annals of Ophthalmology, 1971, 3, 137.

${ }^{17}$ Heller, G, and Sloane, M, Pediatrics, 1950, 5, 836.

18 Watts, J C, Pediatrics, 1962, 30, 592.

${ }^{19}$ Lund, L, European fournal of Clinical Pharmacology, 1974, 7, 119.

20 Gerber, N, Lynn, R, and Oates, J, Annals of Internal Medicine, 1972, 77, 品 765.

${ }^{21}$ Mitchell, J R, and Jollows, D J, Gastroenterology, 1975, 68, 392.

22 Crawford, T B B, Nisbet, H B, and Ritchie, D, fournal of Pharmacy and $\stackrel{2}{2}$ Pharmacology, 1952, 4, 294.

${ }^{23}$ Duma, R J, Hendry, C N, and Donohoo, J S, Southern Medical Fournal, 1966, 59, 168.

${ }^{24}$ Horning, M G, et al, Placental Transfer of Drugs, Fetal Pharmacology, ed L O Boréus. New York, Raven Press, 1973.

\title{
Effect of paracetamol on gastric mucosa
}

\author{
KEVIN J IVEY, G R SILVOSO, WILLIAM J KRAUSE
}

British Medical fournal, 1978, 1, 1586-1588

\section{Summary and conclusions}

The effect of paracetamol on the gastric mucosa was examined in seven healthy volunteers. The dose used ( $2 \mathrm{~g}$ instilled in $100 \mathrm{ml}$ isotonic saline) was equivalent to about six tablets taken with water. Biopsy specimens were taken before and 10 and 60 minutes after instillation. The mean incidence of damaged surface cells in the control period was $1.7 \%$. Ten minutes after instillation $3.5 \%$ of the surface cells were damaged. This increase was not significant. Light microscopy showed focal cell disruption and infiltration of red blood cells. Scanning electronmicroscopy showed minimal loss of normal cell apices. No erosions were seen on microscopy. Biopsy specimens taken 60 minutes after paracetamol showed similar changes.

These findings differ appreciably from the extensive cell damage and microscopic erosions caused by therapeutic doses of $600 \mathrm{mg}$ (two tablets) of aspirin. We conclude that large "analgesic" doses of paracetamol cause minimal ultrastructural changes in normal human gastric mucosa. The continued use of paracetamol in place of aspirin appears to be justified when there is a possibility of gastric mucosal injury.

\section{Introduction}

Paracetamol (acetaminophen (USA)) is commonly used as a substitute for aspirin. Data based on the retail sales of analgesics in pharmacies and on prescriptions in the UK indicate that sales of paracetamol increased from $70 \%$ of aspirin sales in 1965 to $150 \%$ in $1971 .{ }^{1}$ Paracetamol and aspirin have similar analgesic and antipyretic properties. ${ }^{2}$ Nevertheless, confusion has arisen as a result of recent advertising by some aspirin manufacturers, in which the report ${ }^{3}$ of the United States Food and Drug

\footnotetext{
Departments of Medicine and Anatomy, Harry S Truman Memorial Veterans Hospital and University of Missouri Medical Centre, Columbia, Missouri

KEVIN J IVEY, MRCP, FACP, associate professor of medicine G R SILVOSO, MD, fellow in gastroenterology

WILLIAM J KRAUSE, PHD, associate professor of anatomy
}

Administration was quoted to the effect that paracetamol was 0 no safer than aspirin. The report-though not the advertisements-made it clear that this was because of the hepatotoxicity $\vec{v}$ of paracetamol. Nevertheless, because of the hepatotoxicity this seemed to be an appropriate time to re-examine the effects of $\overparen{\Phi}$ the drug on the stomach.

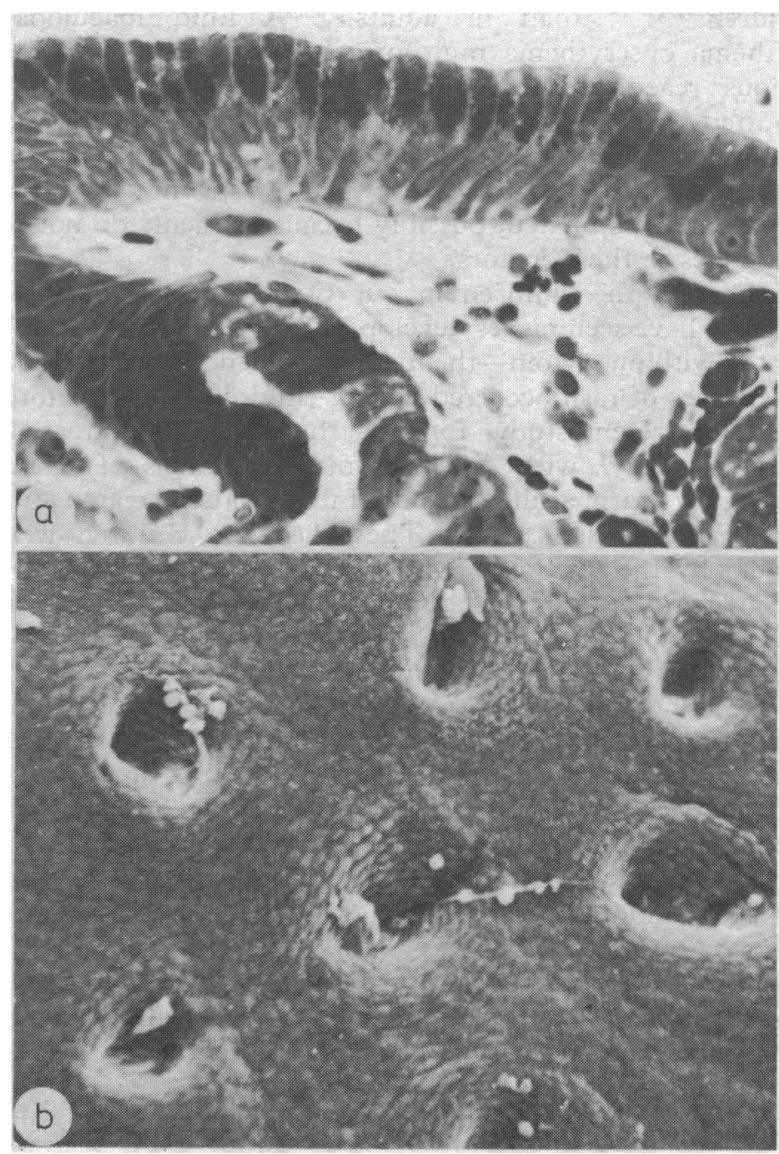

FIG 1-(a) Section of normal gastric mucosa from fundus seen by light microscopy. Mucosal surface is intact. (Epon 812 section (Fisher Scientific Co, Fairlawn, New Jersey); toluidine blue. Original magnification: $\times 400$.) $(b)$ Normal gastric mucosa as viewed from mucosal surface by scanning electron microscopy. Foveolae are evident as well as individual cell apices, giving surface a cobblestone appearance. (Original magnification: $\times$ 400.) 


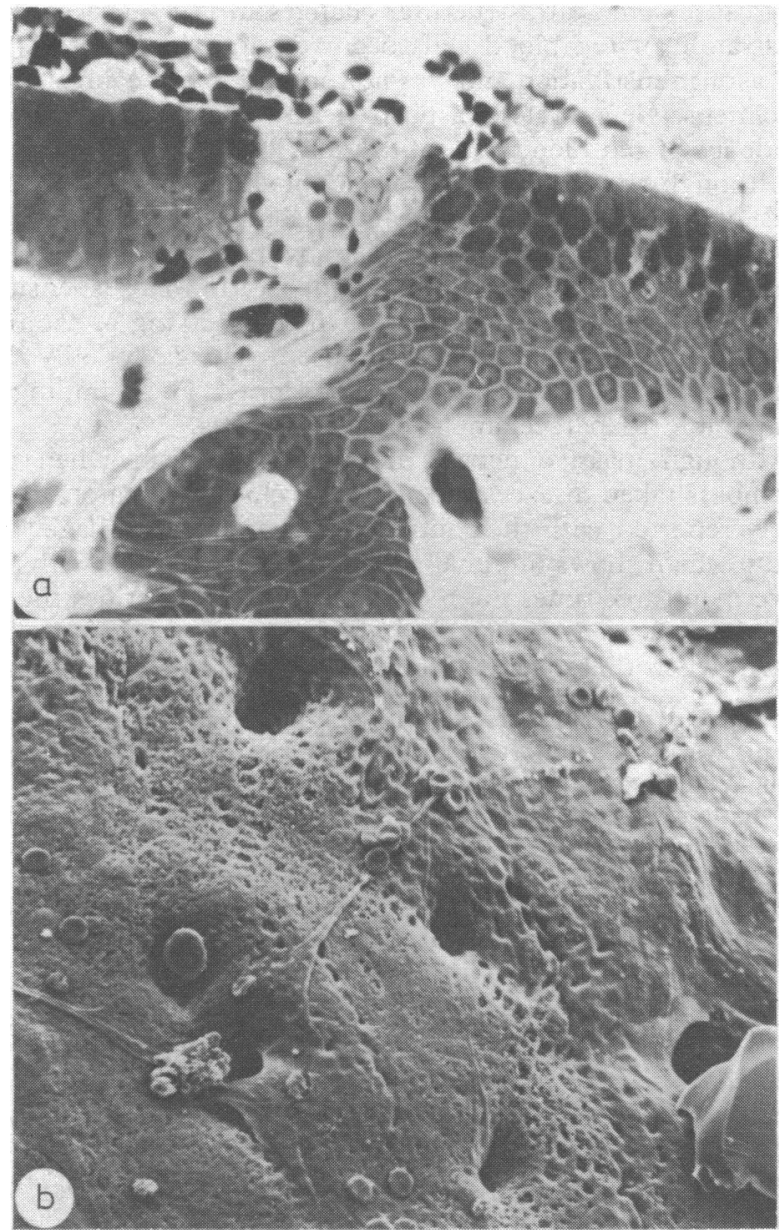

FIG 2-(a) Selected section of fundal gastric mucosa 10 minutes after instillation of paracetamol as seen by light microscopy (most of mucosa appeared normal). Damaged surface cells with disruption of cytoplasm and nuclei are evident. Red blood cells have infiltrated epithelium. (Epon 812 section; toluidine blue. Original magnification: $\times 400$.) (b) Selected area of fundal mucosal surface 10 minutes after instillation of paracetamol as seen by scanning electron microscopy showing maximum damage produced by drug. Localised foci of damaged cells give surface honeycombed appearance. Most damage is confined to regions between foveolae (generally, mucosa appeared normal). (Original magnification: $\times 400$.)

While aspirin may cause gastric bleeding, inflammation, erosions, and ulceration, paracetamol is reputed to be free from gastric side effects. This reputation is based on endoscopic studies and the absence of increased blood loss in the stools of subjects given paracetamol. ${ }^{45}$ Elsewhere we reported that large doses of paracetamol do not damage the gastric mucosal barrier as measured by gastric ionic fluxes and potential difference. ${ }^{\circ}$ These finciings contrast sharply with the disruption of the gastric barrier caused by therapeutic doses of aspirin. ${ }^{78} \mathrm{We}$ also found that aspirin may alter the gastric mucosal ultrastructure, but there have been no histological studies of the effects of paracetamol on the gastric mucosa. We therefore report the ultrastructural effects of large analgesic doses of paracetamol on the gastric mucosa as seen by light and scanning electron microscopy. These structural changes are contrasted with the changes caused by therapeutic doses of aspirin reported by us previously. ${ }^{7}$

\section{Subjects and methods}

The study was carried out on seven healthy fasting volunteers (six men and one woman) aged 21-26 years. Informed consent was obtained before each study in accordance with the principles of the
Declaration of Helsinki. The study was also approved by the institutional human experimentation committee.

Fasting gastric contents were aspirated, and the stomach was washed with $200 \mathrm{ml}$ of isotonic saline to remove residual contents. Gastric biopsy specimens ( $2 \mathrm{~mm}$ in diameter) were obtained with a Quinton hydraulic biopsy tube (Quinton Instruments, Seattle, Washington) positioned under fluoroscopy in the fundus near to the greater curvature. Duplicate specimens (one for scanning and one for light microscopy) were obtained. A suspension of paracetamol, 1950 $\mathrm{mg}$ in $100 \mathrm{ml}$ of isotonic saline (roughly equivalent to six tablets in a small glass of water), was instilled. Duplicate biopsy specimens were taken 10 minutes after instillation. After 30 minutes the gastric contents were aspirated and $100 \mathrm{ml}$ of isotonic saline was reinstilled. Duplicate biopsy specimens were taken again, 60 minutes after the paracetamol instillation. Biopsy specimens were fixed, processed, and examined by light and scanning electron microscopy as described. ${ }^{7}$ Each specimen examined by light microscopy (control, 10 minutes after paracetamol, and recovery) was coded and read separately by a histopathologist. Cell damage was evaluated by counting 500 consecutive surface cells per section. Cells were recorded as damaged if they had nuclear or cytoplasmic changes, or both. Statistical analyses were carried out with Student $\cdot s$ paired $t$ test.

\section{Results}

Normal gastric appearances-Fig 1 shows typical light and scanning electronmicrographs of the normal gastric mucosa. Examination by light microscopy of the biopsy specimens taken from the seven subjects during the control period showed that the incidence of

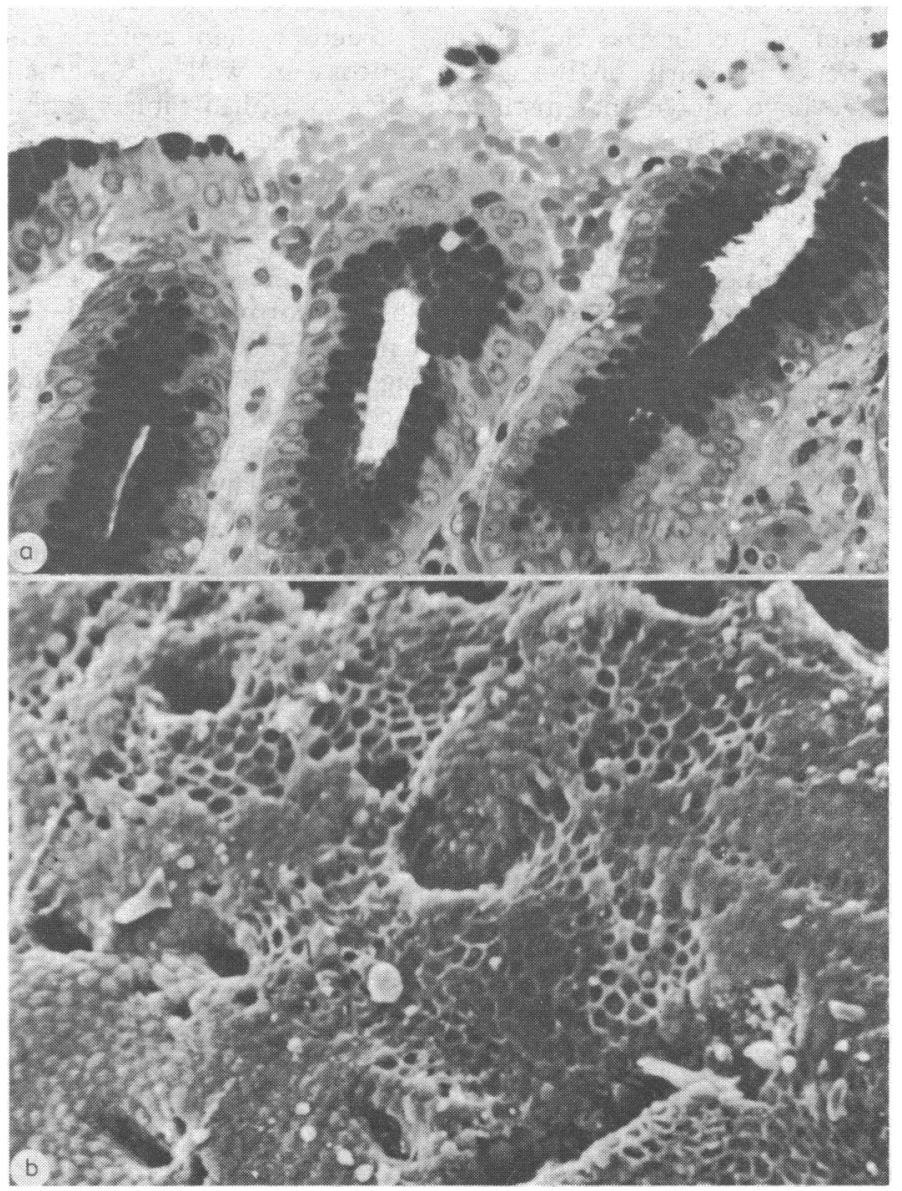

FIG 3-(a) Section of fundal gastric mucosa 10 minutes after instillation of $600 \mathrm{mg}$ aspirin as seen by light microscopy. Note extensive disruption of mucosal lining with areas characterised by total loss of surface cells and haemorrhage. (Epon 812 section; toluidine blue. Original magnification: $\times 400$.) (b) Fundal gastric mucosa 10 minutes after instillation of $600 \mathrm{mg}$ aspirin as viewed by scanning electron microscopy. Note diffuse honeycombed appearance with extensive loss of cell apices; also red blood cells passing through surface and foveolae. (Original magnification: $\times 400$.) 
damaged surface cells was $1 \cdot 7 \pm 0 \cdot 4 \%$ (mean $\pm S E$ ), which was similar to that found previously. ${ }^{9}$ This damage presumably represents normal aging and dying.1011 Scanning electron microscopy of the normal gastric mucosa showed the typical cobblestone appearance of the epithelial surface (fig $1(b)$ ).

Changes induced by paracetamol in saline-Ten minutes after instillation most of the gastric mucosal surface appeared normal. The mean incidence of damaged surface cells was $3.5 \pm 1.5 \%$, which was not significantly different from the control results. Light microscopy showed areas of focal cellular degeneration with loss of toluidinestaining density of cytoplasm, appearance of small vacuoles in the cytoplasm, and degeneration of the nuclear chromatin. These foci of cellular degeneration were infiltrated by red blood cells (fig 2(a)). Scanning electron microscopy showed that most of the mucosa surface was normal, although random areas where the normal cel apices had been lost gave the surface a pitted appearance (fig $2(b)$ ). No erosions were seen by either light or scanning electron microscopy.

Biopsy appearances during recovery period-Light and scanning electronmicrographs of the biopsy specimens taken 60 minutes after paracetamol instillation were similar to the control and 10-minute micrographs. Of the cells counted, $3 \cdot 0 \pm 1 \cdot 6 \%$ were damaged, which was not significantly different from the control values.

In contrast, fig 3(a) shows the appearance of typical gastric erosions present 10 minutes after the ingestion of two aspirin tablets $(600 \mathrm{mg})$ in $100 \mathrm{ml}$ isotonic saline as seen by light microscopy. ${ }^{7} 10$ Fig 3(b) shows the typical extensive aspirin-induced lesions as seen by scanning electron microscopy.

\section{Discussion}

Although paracetamol is commonly used as a substitute for aspirin to avoid gastric mucosal injury, there have been no studies in man showing whether paracetamol causes less damage to the gastric mucosal structure than aspirin. The effects of aspirin on the gastric mucosa are well documented. We have shown that instillation of two aspirin tablets (about $600 \mathrm{mg}$ ) damages $20-25 \%$ of the surface cells within 10 minutes. ${ }^{7}$ Changes in surface cells range from focal cell disruption to microscopic erosions, the erosions being present in over $60 \%$ of biopsy specimens taken at 10 minutes. $^{7}{ }^{910}$ Scanning electron microscopy showed severe honeycombing of the gastric surface secondary to loss of normal cell apices and gastric erosions. ${ }^{7}{ }^{10} \mathrm{In}$ contrast, a much larger dose of paracetamol (1950 mg, or six tablets) damaged only $3.5 \%$ of the surface cells $(\mathrm{P}<0.01)$. Furthermore, paracetamol produced no microscopic erosions of the type produced by aspirin. Aspirin-induced damage to the gastric mucosa may be correlated with changes in the gastric mucosal barrier due to hydrogen ion movement or potential difference. ${ }^{7}$ Conversely, paracetamol in large analgesic doses (six tablets) does not damage the gastric mucosal barrier. $^{6}$
The present study indicates that large doses of paracetamol may cause some ultrastructural changes in the gastric mucosa. Infiltration of red blood cells occurred after both paracetamol and aspirin instillation and was not present in the control biopsy specimens. Nevertheless, aspirin clearly causes a much greater incidence of red blood cell infiltration. ${ }^{7} 910$

Although the effects of paracetamol differ appreciably from $c$ those of aspirin given alone, a comparison may be made between the ultrastructural changes caused by paracetamol and those caused by the instillation of $600 \mathrm{mg}$ of aspirin in a suspension of sodium bicarbonate. We have shown that $600 \mathrm{mg}$ of aspirin in $100 \mathrm{ml}$ of isotonic bicarbonate caused damage to only $3.4 \%$ of the surface cells and no gastric erosions. ${ }^{9}$ These findings are comparable to paracetamol-induced changes.

Although massive hepatic necrosis may occur when para- $\vec{\circ}$ cetamol is taken in excessive amounts, chronic hepatotoxicity is rarely reported with the routinely recommended dosage. ${ }^{12}$ Our $\vec{\omega}$ study, which shows minimal gastric mucosal damage with doses more than three times the recommended dose, justifies the continued preference for paracetamol rather than unbuffered aspirin when there is a possibility of gastric mucosal injury.

This work was supported in part by the Medical Research Service $\vec{F}$ of the Veterans Administration. We gratefully acknowledge the help $\mathscr{\infty}$ and patient care facilities of the University of Missouri Clinical Research Centre.

Requests for reprints should be addressed to: Dr K J Ivey, $\vec{V}$ University of Missouri, Department of Medicine, Division of Gastroenterology, Columbia, Missouri 65201.

\section{References}

${ }^{1}$ Langman, M J S, Australian and New Zealand fournal of Medicine, 1976, 6, 22.

Beaver, W T, American fournal of the Medical Sciences, 1966, 251, 576

${ }^{3}$ Monograph for OTC Internal Analgesic, Antipyrectic, and Antirheumatic Products, Federal Register, vol 42 (No 131), book 2, p 35345. Washington, HEW and FDA, 1900.

${ }^{4}$ Goulston, K, and Skyring, A, Gut, 1964, 5, 463.

5 Vickers, F N, Gastrointestinal Endoscopy, 1967, 14, 94.

${ }^{6}$ Ivey, K J, and Settree, P, Gut, 1976, 17, 916.

${ }^{7}$ Baskin, W, et al, Annals of Internal Medicine, 1976, 85, 299.

${ }^{8}$ Smith, B M, et al, New England fournal of Medicine, 1971, 285, 716.

${ }^{9}$ Bowen, B K, Krause, W J, and Ivey, K J, British Medical fournal, 1977, 2, 1052

${ }^{10}$ MacKercher, P A, et al, Annals of Internal Medicine, 1977, 87, 676.

${ }_{11}$ Croft, D N, American fournal of Digestive Diseases, 1977, 22, 383.

12 Johnson, G K, and Tolman, K G, Annals of Internal Medicine, 1977, 87, 302 .

\title{
Stilboestrol and vaginal clear-cell adenocarcinoma syndrome
}

\author{
JOHN M MONAGHAN, L A W SIRISENA
}

British Medical fournal, 1978, 1, 1588-1590

\section{Summary and conclusions}

A vaginal clear-cell adenocarcinoma developed in a young woman who had been exposed in utero to maternal stilboestrol treatment. During 1940-71 in the UK some 7500 women were given stilboestrol during pregnancy. Thus more cases are likely to appear and clinicians caring for young women should be alert to this possibility.

\section{Introduction}

Stilboestrol has long been incriminated as a transplacental carcinogen. The pathogenesis of these processes is unknown. Ingestion of oestrogen in the first 18 weeks of pregnancy is thought to prevent squamous metaplasia of glandular epithelium in the upper fetal vagina, so that at puberty the ovarian hormones stimulate the persisting glandular epithelium, causing abnormal proliferation. During the 1940 s-60s stilboestrol was used in some British centres to support high-risk pregnancies. All girls resulting from these pregnancies were at risk of developing 